\title{
Xeroderma Pigmentosum: Important Oral Manifestations Case
}

\section{Report}

Guadalupe Josefina Mikel Tostado ${ }^{1 *}$, Caroline Chanussot Deprez ${ }^{2}$, Maria Fernanda Estrada Viveros ${ }^{3}$, Sara Gabriela Nuñez Romo ${ }^{4}$ ${ }^{1}$ Oral Surgery Specialty, General Hospital of Pemex de Veracruz, Miguel Angel de Quevedo S/N, corner Raz y Guzman, Colonia Formando Hogar, 91710, Veracruz.

${ }^{2}$ Dentistry service, General Hospital of Pemex de Veracruz.

${ }^{3}$ Dermatology Service, General Hospital of Pemex de Veracruz.

${ }^{4}$ Dentistry Student, Universidad del Valle de México Campus Veracruz.

*Corresponding Author: Guadalupe Josefina Mikel Tostado, Oral Surgery Specialty, General Hospital of Pemex de Veracruz, Miguel Angel de Quevedo S/N, corner Raz y Guzman, Colonia Formando Hogar, 91710, Veracruz.

Received date: January 31, 2021; Accepted date: March 15, 2021; Published date: March 17, 2021

Citation: Guadalupe J M Tostado, Caroline C Deprez, Maria F E Viveros, Sara G N Romo. (2021) Xeroderma Pigmentosum: Important Oral Manifestations Case Report. Clinical Research and Clinical Trials. 3(1); DOI: 10.31579/2693-4779/023

Copyright: Copyright ( $)$ 2021, Guadalupe Josefina Mikel Tostado, This is an open access article distributed under the Creative Commons Attribution License, which permits unrestricted use, distribution, and reproduction in any medium, provided the original work is properly cited.

\begin{abstract}
The Xeroderma pigmentosum [XP] is a rare inherited skin disorder and transmitted in an autosomal recessive manner. The aim of the present article is to report a XP case with oral manifestations and to discuss the role of the dental professional management of this entity. A 5 year old male presented lentigos all over the skin and predominated in photoexposed areas. Oral hygiene was good and dental affection was important. No lesions were observed in the lips, tongue and the rest of the bucal mucosa but multiples teeth with cavities were observed. Antibiotic treatment was started and surgical treatment. Besides dermatological, ophtamological and neurological management, XP patients require constant dental care and follow -up in order to control the occurrence of new lesions on the lips or inside oral cavity.
\end{abstract}

Key words: xeroderma pigmentosum; skin carcinoma; bucal hygiene

\section{Introduction}

Xeroderma pigmentosum [XP] was first described by Hebra and Kaposi in 1874. 8 years later, in 1882 Moriz Kaposi coined the term "Xeroderma Pigmentosum" which translates to "dry parchment skin" inspired by its characteristic dry skin with lentigos [freckling of the skin] $[1,2]$.

The Xeroderma pigmentosum is a rare inherited skin disorder caused, in $80 \%$ of the patiens, by a defect in DNA nucleotide excision repair mechanisms [NER; DNA) and transmitted in an autosomal recessive manner. It is characterized by photosensitivity, pigmentary changes, premature skin aging, and malignant tumor development. In $20 \%$ of the patients, the defect is in the DNA replication, there is formation of new DNA from a damaged DNA: (XP variants) $[1,2,3]$.

Eight forms of the disease are recognizable according to the features of the molecular defect and clinical aspects [4]. The clinical variant XP-C is the most founded in the United States, Europe and North of Africa, and, XP- subtype A is more frequent in Japan [2]. High Frequency of consanguinity has been reported [30\%] [5].

The incidence in the United States and Europe is one case per million habitants, in Africa and Japan, the incidence is ten times more elevated [5].
Patients with XP have 10000 times more risk to present non melanoma skin cancer and 2000 more risk to present a melanoma. In $91 \%$ of the patients there is ocular manifestations and $24 \%$ of the patients present neurologic manifestations. Also XP patients have higher risk of developing certain cancers like neurologic neoplasias [6, 7].

The aim of the present article is to report a XP case with oral manifestations and to discuss the role of the dental professional management of this entity.

\section{Case report}

The family is composed by the mother [ 40 years old], the father [ 43 years old], it is important to add that our patient's parents are cousins [their mothers are sisters]. They have 2 more children, a 20 year old boy and a 10 year old girl who are clinically healthy. The third boy, a 5 year old, is our patient with XP and in this article we will be describing his skin and buccal manifestations.

A 5 year old male presented with hyperpigmented macules and papules all over the skin and predominated in photoexposed areas, with xerotic skin (figure 1 and 2). 

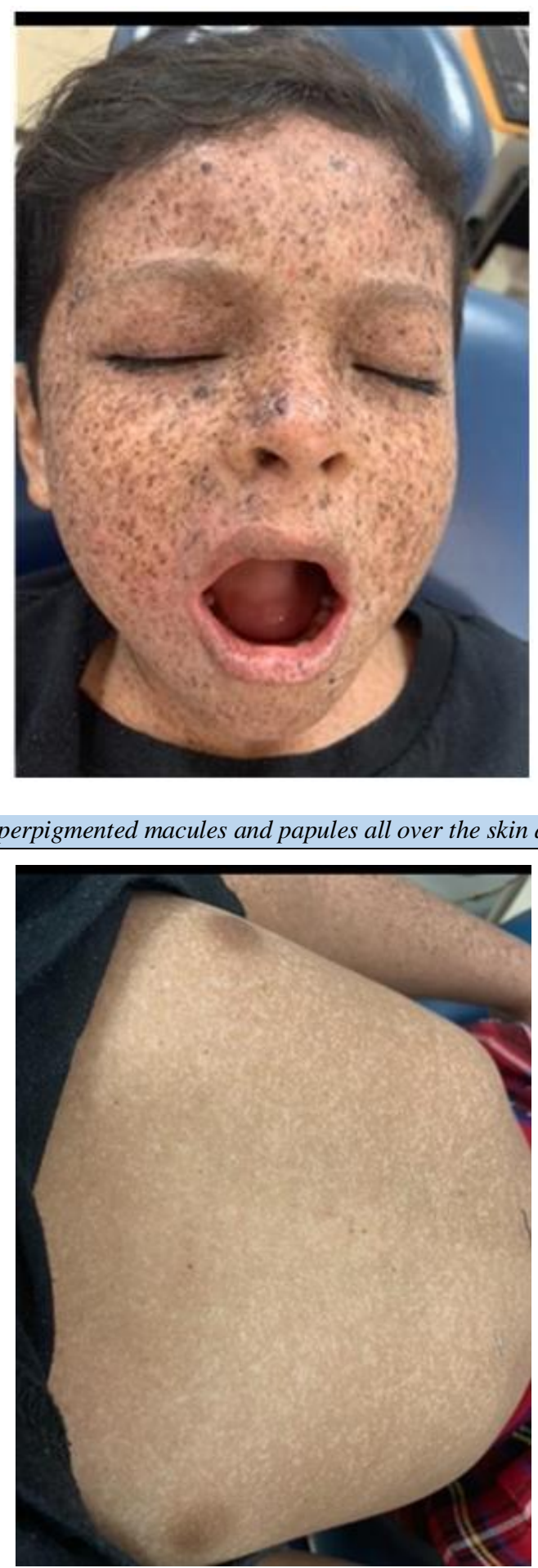

Figure 2: 5 year old with hyperpigmented macules and papules all over the skin in the torax.

Our patient's mother explained to us that from the appearance of the primary dentition, they had "White spots and crumbled easily". She noticed that the teeth were fragile. They went for a check-up at a dental clinic where the child and her received care, the brushing technique was explained to him and he received dental treatment based on periodic cleaning, application of chlorhexidine and fluoride varnish. Before age 2, he had already received treatment based on pulpectomies and placement of chrome-steel crowns.
Upon revision, good oral hygiene was observed, soft tissues [lips, tongue, cheek mucosa] without lesions; significant enamel hypoplasia, with areas of mottled enamel. The patient has a significant predisposition to caries since he presents caries at teeth 51, 52, 54, 55, 61, 62 (figure 3 and 4). Also a retained root at 64 , which caused an infectious process with fistula. The patient began an antibiotic treatment and subsequently an extraction of the retained root. 


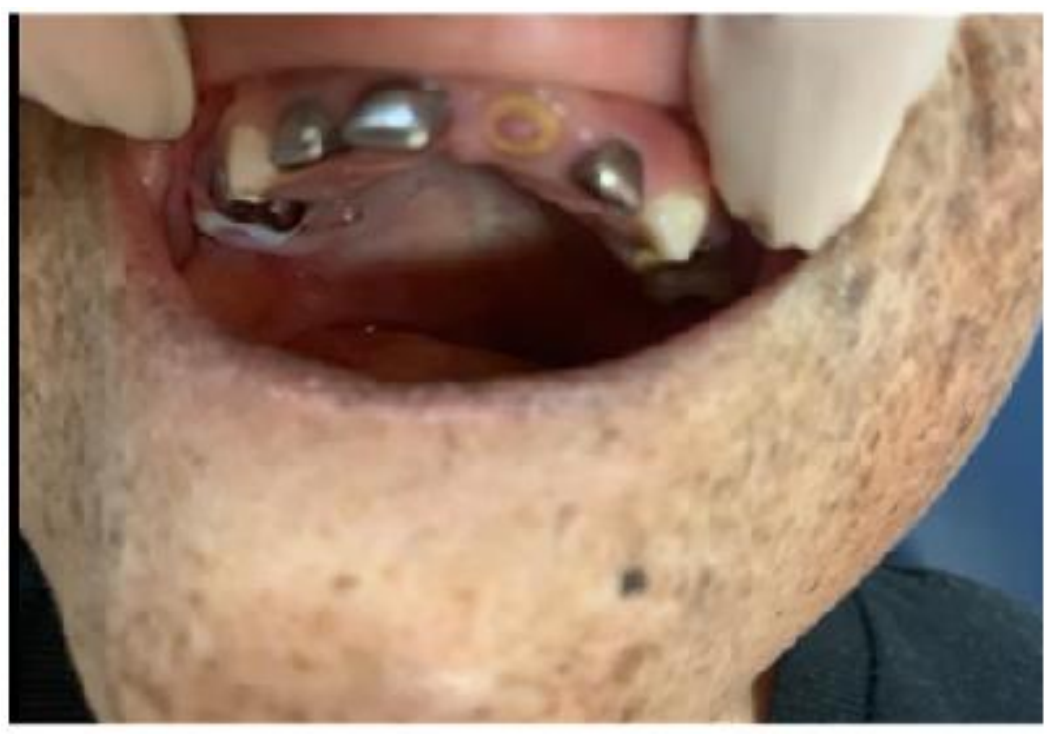

Figure 3: Significant enamel hypoplasia and caries, several teeet with chrome-steel crowns

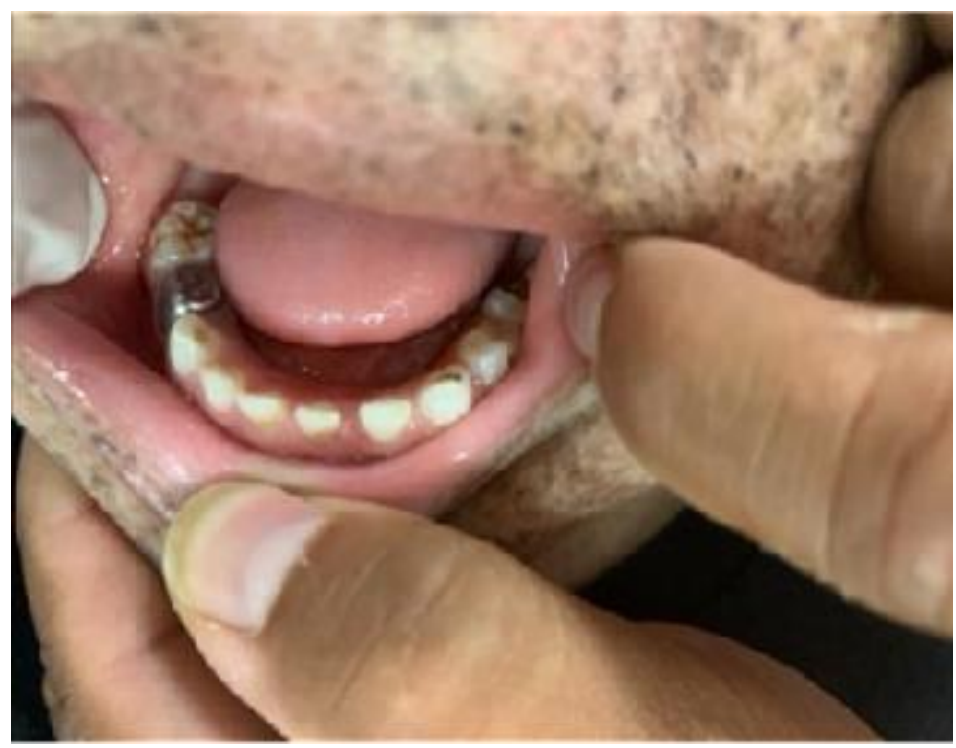

Figure 4: Significant enamel hypoplasia and caries, several teeet with chrome-steel crowns.

During medical history assessment, the mom reported the boy was evaluated by a genetist and XP-C variant was identified in our patient.

She also reported the removal of three skin lesions, a month ago, in the face (the front, inferior right eyelid and the nose), all three of them sent to pathology and coming back with a result of epidermoid carcinoma.

Currently he is been evaluated by a plastic surgeon and pediatric oncologist for a new skin tumor that appeared next to a surgical scar of the patients forehead.

Ophtamologist consultations are every 6 months and he has no ocular affectations.

He goes to preschool and he is learning well, he has friends. He has no neurologic manifestations, except the difficulty to pronounce some consonants.

\section{Discussion}

Our little patient history with XP begins when he had 9 months old with erythema, bullae in the photoexposed skin after sun exposition. Rapidly, he presented multiples lentigos in the face, neck, arms and legs.

He was evaluated by a genetist and the genetic study confirmed the diagnosis of XP, C variant. The XP is characterized by a defect in DNA nucleotide excision repair mechanisms (NER; DNA). NER may be subdivided into transcription-coupled repair and global genome repair, and the XPC protein is specific to this latter repair pathway recognizing helix distorting lesions and initiating their repair. Inactivating XPC mutations are associated with XP and an extremely high risk of skin cancer [8].

In our patient, skin cancer appeared very soon, at 5 years old. In patients with XP, skin cancer can begin between one and 32 years old and predominate at 9 years old for non-melanoma skin cancer and 22 years old for melanoma. [2, 5, 9]. 
The oral manifestations are mainly related to the occurrence of malignant tumor in the lips, tongue and buccal mucosa. In $79 \%$ of the patients with XP teeth malformations and carcinomas can be observed $[1,10,11]$.

Also, in some patients successive labial plasty for the treatment of actinic cheilitis can produce microtomy and affect oral hygiene performance [1].

In our little boy, buccal manifestations were important and required attention and professional treatment, this is why we believe dental approach in XP patients is very necessary for their management; especially with cancer in oral and perioral region being high risk patients. Clinical examination carried out regularly by the dentist is mandatory for the detection of premalignant or malignant lesions. Furthermore, it is necessary to establish protocols for prophylaxis and topical fluoride application, as well as the use of chlorhexidine digluconate $0.12 \%$ aiming at the homeostasis of the oral environment. The use of mouth washes with high alcohol concentration should be avoided because there is an increased risk of developing oral cancer in these patients [12].

Finally, the main oral manifestations of XP are actinic cheilitis, basal cell and squamous cell carcinomas.

Besides dermatological, ophthalmological and neurological management, XP patients require constant dental care and follow up in order to control the occurrence of new lesions on the lips or inside oral cavity.

The authors declare no conflict of interest.

\section{References}

1. Lopes Cardoso C, Paes da Silva Ramos Fernandes LM, Ferreira Rocha J, Teixera Soares C, Barreto JA, Damante JH. (2012) Xeroderma Pigmentosum-A case report with oral implications. J Clin Exp Dent. 4(4): 248-251.

2. Cheirif-Wolosky O, Palacios Lopez C. (2017) Opciones terapéuticas y preventivas no invasivas para el cáncer de piel no melanoma en pacientes pediátricos con xeroderma pigmentoso. Dermatología CMQ. 16(1):83-90.
3. Xeroderma. (2007) Pigmentosum-Protocole national de diagnostic et de soins pour une maladie rare. Haute Autorité de Sante.

4. Inui H, Oh KS, Nadem C, Ueda T, Khan SG, Metin A, et al. (2008) Xeroderma pigmentosum-Variant patients from America, Europe and Asia.J Invet Dermatol. 128:2055-2068.

5. Faller AS, Mancini AJ. (2011) Xerodrma pigmentoso.En Hurwitz clinical pediatric ermatology, Cambridge, Elsevier. 455-457.

6. LiyW MC, Duran McKinster C, Orozco L, Saez Ocariz MM, Carrasco D, Ruiz Maldonado R. (2004) Xeroderma pigmentoso con retraso psicomotor: síndrome de Sanctis Cacchione.Reporte de 2 casos de origen mexicano. Dermatol Pediatr lat. 2(1): 50-53.

7. Bradford PT,Goldstein AM, Tamura D et al. (2011) Cancer and neurologic degeneration in xeroderma pigmentosum:long term follow up characterizes the role of AND repair.J med Genet. 48:168-176.

8. Nelson HH, Christensen B, Karagas MR. (2005) The XPC poly-AT polymorphism in non melanoma skin cancer. Cancer let. 222(2): 205-209.

9. Black JO. (2016) Xeroderma pigmentosum, Head and neck Pathol. 10:139-144.

10. Rodriguez Garcia R, Aguilar Ye A, Puig Sosa PJ, Solis Daun O, Padilla Castillo A. (2002) Xeroderma pigmentoso en dos hermana. Rev Mex Pediatr. 69(4):151-154.

11. Chidzonga MM, Mahomva L. Makunike-Mutasa R. Masanganise R. (2009) Xeroderma pigmentosum: a retrospective case series in Zimbabwe.J Oral Maxillofac Surg. 67:22-31.

12. Scully C. (1995) Oral Precancer: preventive and medical approaches to management. Eur J B Cancer Oral Oncol. 31:1626.
This work is licensed under Creative Commons Attribution 4.0 License

To Submit Your Article Click Here: Submit Manuscript

DOI: $10.31579 / 2693-4779 / 023$
Ready to submit your research? Choose Auctores and benefit from:

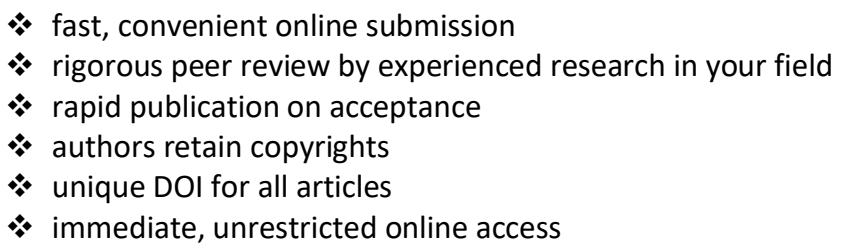

At Auctores, research is always in progress.

Learn more www.auctoresonline.org/journals/clinical-research-andclinical-trials 